\title{
The Analysis of Cost Quality on Productivity of Iron Railing Products in Small and Medium Business in Palembang
} (Impirical Study of Iron Railing Products in Palembang)

\author{
M. Thoyib ${ }^{1, *}$ Riza Wahyudi ${ }^{1}$ Firmansyah Firmansyah ${ }^{1}$ Darul Amri $^{1}$
}

\author{
${ }^{1}$ State Polytechnic of Sriwijaya \\ *Corresponding author.Email: thoyib1958@gmail.com
}

\begin{abstract}
This study aims to determine and analyze the Effect of Quality Costs on Work Productivity in Small and Medium Enterprises in Palembang (Impirical Study of SME Iron Railing Products in Palembang City). With a sample of 120 SME respondents from the existing population, the sample was taken using purposive sampling. The data was gathered through questionnaire that has been tested for validity and reliability. Using the Multiple Regression model with statistical analysis of the SPSS version 22 application, the results showed that the effect of quality costs consisting of prevention costs, assessment costs, internal and external failure costs had a positive and significant effect on work productivity both partially and simultaneously. With the quality cost report, it can be concluded that it has implications for low external failure activities, in the form of handling complaints, warranties, and recalls.
\end{abstract}

Keywords: Cost quality, prevention cost, assessment cost, internal and external failure costs, productivity

\section{INTRODUCTION}

The main objective of the business is none other than the achievement of optimal profit in every business operations. Profit refers as an increase in total sales/revenues and a decrease in operating costs and expenses. This is also shown in the gradual increase in market share, both in product lines and market areas. The same with Micro, Small and Medium Enterprises (MSMEs), starting with a micro scale and develops into small and sustainable medium-sized enterprises, and if managed effectively and efficiently they will become large businesses/companies. This will become real if it is carried out with professional management techniques and management in all fields of the company; such as marketing, finance, human resources and production.

In this study the emphasis is on the financial sector, especially focusing on the quality cost system (Prevention; Quality training, Quality design, Reliability engineering, model testing, Assessment; Design review, Material inspection, Reliability testing, Machine inspection, Laboratory testing, Process acceptance. Failure internal; Waste materials, Repairs, Re-spelling, Production Jams, Machine breakdowns, Waste disposal and External failures; Warranty costs, Product replacement, Customer complaints, Product recalls, Product-related liabilities, Loss of Sales, Loss of market share) on work productivity. The study of the quality cost measurement system according to experts can only be done in large companies. The researcher assumes that empirically this measurement can also be carried out on MSMEs either jointly or alone. In principle, quality costs are costs incurred due to low quality, company doing things wrong or doing activities that are not needed directly to support company goals.

Meanwhile, productivity is a concept that shows the existence of links between performance and time units used to produce a product from a workforce or employee. Productivity measurement is actually the relationship between output and input in a productive system with performance indicators such as; presence of service, Aesthetics, product appereanc, Serviceability, 
ease of maintenance of the product, Features, that distinguish a product, Reliability of product opportunities in the long term, Length of time the product is used, Quality of conformity, conformity to design, Suitability in use, presence of product in function. The relationship between quality costs and productivity will be examined in a multiple regression model partially or simultaneously, after which it is calculated and reported in the quality cost report.

\section{LITERATURE REVIEW}

Quality cost according to JM. Juran (2016: 4) is costs that are "associated solely with defective productsthe costs of making, finding, repairing, or avoiding defects In Indonesian, quality costs can be interpreted as costs associated solely with products that are Defects are the costs of making, finding, repairing, or avoiding defective products.

According to Blocher, Chen, Lin (2019: 220) which is translated by Sasty Ambariani are as follows: The costs associated with the prevention, identification, repair, and repair of low-quality products, and with the "opportunity cost" of lost production time and sales as a result of poor quality.

According to Handoko.H (2018), productivity is the relationship between output and input in a productive system. The purpose of measuring productivity is consumer expectations for products and services, these expectations can be seen from the following indicators such as; Performance; presence of service, Aesthetics, beautiful appearance of the product, Serviceability, ease of maintenance of the product, Features, that distinguish a product, Reliability of product opportunities in the long term, Length of time the product is used, Quality of conformity, conformity to design, Suitability in use, presence of product in function Badrik et al (2017: 187).

The company's quality costs need to be presented in the form of quality cost reports periodically, generally on a monthly basis. Presentation of quality cost reports based on quality cost classifications namely prevention costs, appraisal costs, internal failure costs, and external failure costs. Each component of the quality cost is added up to obtain the total cost. Furthermore, each component of the total quality cost is compared with sales using a common-size analysis. The quality cost structure is in accordance with the quality cost concept, that if prevention and appraisal activities in quality improvement are low, as indicated by relatively small prevention costs, which is only $1.5 \%$ of sales, it will have implications for high external failure activities, in the form of handling complaints, warranty, and recall. Quality cost reports should also be presented in the form of trends in order to know the development of quality costs over a certain period.

\section{RESEARCH METHOD}

Scalar variables and physical constants should be The population in this study is Small and Medium Enterprises in the Processing/Industrial Sector, especially the door and window trellis industry in the city of Palembang, South Sumatra, as many as those registered with the Cooperative Industry and Trade Office (2015-2021). By taking samples that can be represented as many as 120 respondents, which is indicated by medium-scale capital entrepreneurs. The sampling technique in this study used purposive sampling, which is part of non-probability sampling. Umar Sekaran (2019:130)

According to Sugiyon (2017:79), the formula to calculate the sample size from a known population is as follows:

$$
S=\frac{\lambda^{2} \cdot N \cdot P \cdot Q}{d^{2}(N-1)+\lambda^{2} \cdot P \cdot Q}
$$

Notes: $\lambda^{2}$ with $\mathrm{dk}=1$, error rate $1 \%, 5 \%, 10, \%$

$$
\mathrm{P}=\mathrm{Q}=0,5, \mathrm{~d}=0,05, \mathrm{~s}=\text { Number of }
$$

sample

The data in this study were collected by means of surveys through interview techniques and questionnaires that have been tested for the validity of each questionnaire item and the reliability of each group of variables, as well as by means of observation. The data is analysis using multiple regression model through SPSS 22.

\section{RESULT AND ANALYSIS}

The t-test is a test to see the influence of each independent variable individually on the dependent variable. This test can be done by comparing t-count and t-table, if t-count $>\mathrm{t}$-table (Ho is rejected or Ha is accepted) and the level of confidence used is $95 \%$ or a significant level of $5 \%$. To measure the effect of the independent variable partially on the dependent variable, it can be seen from the analysis of the coefficients table in table 1 . below: 
Table 1. Coefficients ${ }^{\mathrm{a}}$

\begin{tabular}{|c|c|c|c|c|c|}
\hline \multirow[t]{2}{*}{ Model } & \multicolumn{2}{|c|}{ Unstandardized Coefficients } & \multirow{2}{*}{$\begin{array}{c}\text { Standardized } \\
\text { Coefficients } \\
\text { Beta } \\
\end{array}$} & \multirow[b]{2}{*}{$\mathrm{t}$} & \multirow[b]{2}{*}{ Sig. } \\
\hline & $\mathrm{B}$ & Std. Error & & & \\
\hline (Constant) & 14.421 & 11.152 & & 1.293 & .199 \\
\hline X1ByPence & .508 & .165 & .259 & 3.075 & .003 \\
\hline X2ByPenil & .333 & .150 & .187 & 2.219 & .028 \\
\hline X3ByKegai & .400 & .178 & .190 & 2.254 & .026 \\
\hline X4ByKegaeks & .343 & .139 & .208 & 2.470 & .015 \\
\hline
\end{tabular}

a. Dependent Variable: YProd

Prevention Costs variable has a p-value of $0.003<$ 0.05 (alpha 5\%) which means it is significant, while tcount $3.075>1.96$ means that Ho is rejected and $\mathrm{Ha}$ is accepted indicating that Prevention Costs have a partial effect on Work Productivity. A positive t-count means that the effect is positive, that is, if the cost of prevention increases, work productivity also increases.

The valuation cost variable has a p-value of 0.028 $<0.05$, which is significant, while t-count is $2.219>\mathrm{t}$ table 1.96, this means that Ho is rejected. Therefore, Ha is accepted, meaning that the cost of the assessment has a partial effect on work productivity. A positive t-count value means that the effect is positive, that is, if the cost of the assessment increases, productivity will increase.

The internal failure cost variable has a p-value of $0.026<0.05$, which means it is significant, while the tcount is $2.254>$ t-table 1.96 , this means that Ho is rejected. Ha is accepted, it means that the cost of internal prevention has a partial effect on work productivity. A positive t-count means that the effect is positive, that is, if the cost of internal prevention increases, productivity will also increase.

The variable cost of assessment has a p-value of $0.015<0.05$, which means it is significant, while the tcount is $2.470>\mathrm{t}$-table 1.96, indicating that $\mathrm{Ho}$ is rejected. Therefore, $\mathrm{Ha}$ is accepted, showing that the cost of external prevention has a partial effect on work productivity. A positive t-count indicates that the effect is positive, that is, if the cost of external prevention increases, productivity will increase.

The $F$ test is a test to see the influence of all independent variables together on the dependent variable. The $\mathrm{F}$ test can be done by comparing the Fcount with the F-table. If F-count > F-table (Ho is rejected, $\mathrm{Ha}$ is accepted) then the model is significant. To measure the effect of independent variables simultaneously/together on the dependent variable, it can be seen from the analysis of table 2. The following ANOVA:

Table 2 ANOVA $^{\mathrm{b}}$

\begin{tabular}{|l|r|r|r|r|r|}
\hline Model & \multicolumn{1}{|c|}{$\begin{array}{c}\text { Sum of } \\
\text { Squares }\end{array}$} & df & $\begin{array}{c}\text { Mean } \\
\text { Square }\end{array}$ & F & Sig. \\
\hline Regression & 289.492 & 4 & 72.373 & 6.748 & $.000^{\mathrm{a}}$ \\
Residual & 1233.308 & 115 & 10.724 & & \\
Total & 1522.800 & 119 & & & \\
\hline
\end{tabular}

a. Predictors: (Constant), X4ByKegaeks, X2ByPenil,

\section{X1ByPence, X3ByKegai \\ b. Dependent Variable: YProd}

From the results of the calculation in Table 2. It can be seen that F-count $6.748>$ F-table 3.068 and P-value of $0.000<0.05$, which means that the independent variables simultaneously have an effect on dependent variable. It means variable; assessment costs (X1), assessment costs (X2), internal prevention costs (X3) and external prevention costs (X4) together have an effect on work productivity (Y).

To measure the magnitude of the relationship between the independent variable and the dependent variable, coefficient of the determinant or the value of $\mathrm{R} 2$ can be used. The results of R2 is 0.690 or $69 \%$ which shows a strong relationship between the variables of prevention costs, assessment costs, internal failure costs and external failure costs on performance productivity as the $\mathrm{R} 2$ value is close to $100 \%$ or a value of 1 (above $50 \%$ ). This also indicates that the variation in performance productivity can be explained by variations in prevention costs, appraisal costs, internal failure costs and external failure costs from the four 
independent variables by $69 \%$, while the remaining $31 \%$ is explained by other reasons outside the model.

The quality cost structure in the quality cost report in this study shows that prevention costs are relatively small, namely $1.5 \%$ of the level of sales, the implication is the low activity of external failure, in the form of handling complaints, warranty, and recall of the marketed products.

\section{CONCLUSION}

1. Partially and simultaneously the costs of Prevention, Assessment Costs, Internal Failure Costs and External Failure Costs have a positive effect on work productivity in MSMEs in Palembang.

2. Productivity can be explained by variations in quality costs (prevention costs, appraisal costs, internal failure costs, external failure costs) by $69 \%$.

3. The quality cost structure is in accordance with the quality cost concept, that if prevention and appraisal activities in quality improvement are low, as indicated by relatively small prevention costs, which is only $1.5 \%$ of sales, it will have implications for low external failure activities, in the form of complaint handling, warranty, and recall

\section{REFERENCES}

[1] Badric Siregar, Bambang Suripto, Dody Hapsoro, Eko Widodo Lo, Frasto Biyanto (2017). Akuntansi manajemen, Jakarta: Salemba Empat.

[2] Hansen dan Mowen,1999, Alih Bahasa Ancella A. Awemawan, Akuntansi manajemen. Edisi 4. JAkarta

[3] Hani Handoko (2018), Manajemen, FEUGM, Yogyakarta.

[4] Daft, Richard. 2003. Manajemen. Eisi ke-5 Jilid 1 dan 2. Erlanggan, Jakarta

[5] Daryanto (2014) Bagaimana Berwiraswasta, books google , co.id.

[6] Don R. Hasen, Maryanne M. Mowen (2018). Akuntansi manajerial, Buku 1, Edisi 8. Jakarta : Salemba Empat

[7] Dessler, Gary. (1994). Managing Organiztions. Philadelphia: Harcourt Brace College Publisher.

[8] Griffin, Ricky W and Ebert, Ronald J, 2006. Business, 8th edition, Pearson Education Inc, New Jersey
[9] Griffin, Ricky W. 2005. Fundamental of Management. 4th Houghton Mifflin Company

[10] Hansen dan Mowen,1999, Alih Bahasa Ancella A. Awemawan, Akuntansi manajemen. Edisi 4. JAkarta

[11] Madura, Jeff. 2007. Introduction to Business. 4th South-Western College Publishing, USA

[12] Mulyadi. (2019). Akuntansi Manajemen, FEUGM, ed 3: Yogyakarta,

[13] M.Thoyib, et al (2017). Determination of Performance Accountability of Local Government Organizations, Jurnal Terapan Manajemen dan Bisnis, STKIP.Singkawang Indonesia.

[14] Rambat L, Ridho B (2019), Praktikum Metode Riset Bisnis,Salemba Empat : Jakarta.

[15] Robbins, S. And Coulter, M. 2002. Management. 7th Prentice Hall, Inc. Upper Sadle River, New Jersey

[16] Sugiyono,2017, Metode Penelitian Bisnis, Bandung, Alfabeta.

[17] Umar Sakaran, (2017),Metode Penelitian untuk Bisnis, Salemba Empat: Jakarta.

[18] Arie Erviansyah,(2013),"Analisis Pengaruh Biaya Kualitas Terhadap Produk Rusak Pada PT. Nusa Toyotetsu Corporation” Th 2013. Hal 1.

[19] Franciscus Lomban Gol dkk. (2020)"Analisis Biaya Kualitas Dalam Meningkatkan Efisiensi Biaya Produksi Pada PT Medan Media Grafikatamatama Tahun 2012-2016", Research and Analysis Journal, ISSN: 2589-9228 | 2589-921X, Vol 3 No 06 (2020) | Page No.: 236 -252

[20] Hastari Ningtyas,(2018),’Pengaruh Biaya Kualitas Terhadap Jumlah Penjualan Pada PT. FajarAgung Medan” Vol. 18 No. 1. Th 2018. Hal 1.

[21] Kristina Meisella Ransum,2016,'Pengaruh Biaya Kualitas Dan Biaya Produksi Terhadap Peningkatan Kualitas Produk Pada Trinity Percetakan Manado" Vol 16, No 04. Th2016. Hal 79.

[22] Lasca Radellia dkk (2021),"Pengaruh Biaya Promosi, Biaya Kualitas, Pertumbuhan Penjualan Terhadap Perubahan Laba Bersih"; JurnaL Korelasi;ISSN 2722-1040, vol 2 No.1

[23] Tandiontong, Mathius and Sitanggang, Fentri and Carolina, Verani (2010)"Pengaruh Biaya Kualitas Terhadap Tingkat Profitabilitas Perusahaan (Studi Kasus pada The Majesty Hotel and Apartment, Bandung).; Jurnal Ilmiah Akuntansi, 1 (2). 
[24] Ridel Tambingon, Herman Karamoy, Sonny Pangerapan (2020)"Analisis pengaruh biaya kualitas dalam meningkatkan profitabilitas perusahaan PT. Putra Karangetang; Indonesia Accounting Journal; Vol 2, No 1,

[25] Yuli Nawangsasi (2007)"Analisis Dampak Biaya Kualitas Terhadap Produktivitas Produksi [9] A.
Pnueli, In transition from global to modular temporal reasoning about programs, in: K.R. Apt (Ed.), Logics and Models of Concurrent Systems, Springer, Berlin, Heidelberg, 1984, pp. 123-144. DOI: https://doi.org/10.1007/978-3-642-82453-1_5 